\title{
A six-year descriptive epidemiological study of human coronavirus infections in hospitalized patients in Hong Kong
}

\author{
Cyril C. Y. Yip ${ }^{1}$, Carol S. F. Lam ${ }^{1}$, Hayes K. H. Luk ${ }^{1}$, Emily Y. M. Wong ${ }^{1}$, Rodney A. Lee ${ }^{4}$, Lok-Yee So ${ }^{5}$, \\ Kwok-Hung Chan ${ }^{1}$, Vincent C. C. Cheng ${ }^{1}$, Kwok-Yung Yuen ${ }^{1,2,3}$, Patrick C. Y. Woo ${ }^{1,2,3 \bowtie}$, \\ Susanna K. P. Lau ${ }^{1,2,3 凶}$
}

1. Department of Microbiology, The University of Hong Kong, Hong Kong SAR, China

2. Research Centre of Infection and Immunology, The University of Hong Kong, Hong Kong SAR, China

3. State Key Laboratory of Emerging Infectious Diseases, The University of Hong Kong, Hong Kong SAR, China

4. Department of Microbiology, Pamela Youde Nethersole Eastern Hospital, Hong Kong SAR, China

5. Department of Paediatrics and Adolescent Medicine, Pamela Youde Nethersole Eastern Hospital, Hong Kong SAR, China

We conducted a six-year epidemiological study on human coronaviruses (HCoVs) circulating in Hong Kong, using 8275 nasopharyngeal samples from patients with acute respiratory tract infections. HCoVs were detected in $77(0.93 \%)$ of the samples by a pan-HCoV RT-PCR assay. The most frequently detected HCoV species was HCoV-OC43 $(0.58 \%)$, followed by HCoV-229E $(0.15 \%)$, HCoV-HKU1 $(0.13 \%)$ and HCoV-NL63 $(0.07 \%)$. HCoVs were detected throughout the study period (September 2008-August 2014), with the highest detection rate from September 2010 to August 2011 (22/1500, 1.47\%). Different seasonal patterns of each HCoV species in Hong Kong were noted. $\mathrm{HCoV}-\mathrm{OC} 43$ was predominant in the fall and winter, whereas HCoV-HKU1 showed peak activity in winter, with a few cases occurred in spring and summer. HCoV-229E mainly occurred in winter and spring, while HCoV-NL63 was predominant in summer and autumn. HCoVs most commonly infect the elderly and young children, with median age of 79.5 years (range, 22 days to 95 years). Intriguingly, the detection rate of HCoV-OC43 in the age group of $>80$ years $(26 / 2380,1.09 \%)$ was significantly higher than that in the age group of $0-10$ years $(12 / 2529,0.47 \%)(P<0.05)$. These data provides new insight into the epidemiology of coronaviruses.

\section{KEYWORDS epidemiology; human coronaviruses; respiratory tract infections}

\section{INTRODUCTION}

Since the severe acute respiratory syndrome (SARS) epidemic in 2003 (Peiris et al., 2003), there has been a boost

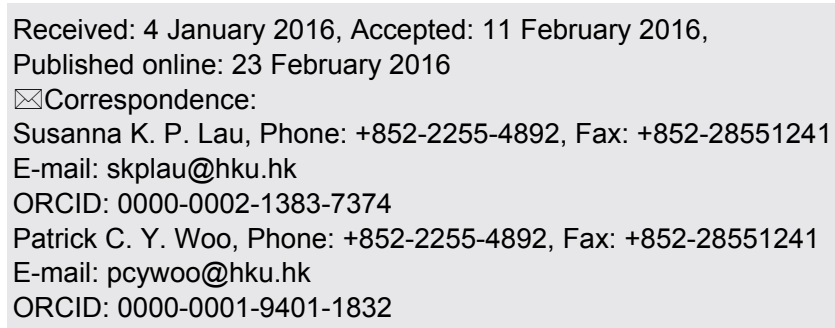

in the interest in the identification of novel coronaviruses (CoVs). Human coronavirus NL63 (HCoV-NL63) was discovered in the Netherlands in 2004 (Fouchier et al., 2004; van der Hoek et al., 2004) and HCoV-HKU1 was identified from two patients with pneumonia in Hong Kong in 2005 (Woo et al., 2005a). Another novel CoV, Middle East Respiratory Syndrome CoV (MERS$\mathrm{CoV}$ ), which first emerged in the middle east region in 2012 (Assiri et al., 2013), can cause severe respiratory distress in patients with high mortality rate of $40 \%$ (Zumla et al., 2015). A recent outbreak of MERS-CoV occurred in health care facilities in South Korea due to a 
superspreading event (Oh et al., 2015). Thus, the impact of coronaviruses on public health cannot be ignored and continuous surveillance is required to monitor diseases caused by newly emerging coronaviruses and the changes in the epidemiology of known human coronaviruses.

$\mathrm{HCoV}-229 \mathrm{E}$ and $\mathrm{HCoV}-\mathrm{OC} 43$ were responsible for $5 \%-30 \%$ of human respiratory tract infections (Hu et al., 2014; McIntosh et al., 1970), while HCoV-NL63 was found to be present in $1.2 \%-9.3 \%$ of the respiratory samples in several studies (Arden et al., 2005; Bastien et al., 2005; Chiu et al., 2005; Ebihara et al., 2005; Koetz et al., 2006; Moes et al., 2005; van der Hoek et al., 2006). We have previously reported the prevalence of $\mathrm{HCoV}$ HKU1 among patients with community-acquired pneumonia in Hong Kong during a one-year period and $\mathrm{HCoV}-\mathrm{HKU} 1 \mathrm{was}$ detected in the nasopharyngeal aspirates (NPAs) of $10(2.4 \%)$ of 418 patients with community-acquired pneumonia (Woo et al., 2005b). Subsequently, we also compared the epidemiology and clinical spectrum of disease of HCoV-HKU1, HCoV-OC43, HCoV-229E and HCoV-NL63 infections in patients hospitalized for acute respiratory illness during a one-year period, which showed that $87(2.1 \%)$ of 4181 NPAs were positive for various HCoVs (Lau et al., 2006).

To date, most of the epidemiological studies of $\mathrm{HCoV}$ infections have included specimens from children only (Chung et al., 2007; Esposito et al., 2006; Kaplan et al., 2008; Kuypers et al., 2007; Pierangeli et al., 2007; Prill et al., 2012; Theamboonlers et al., 2007; Vabret et al., 2008; van der Hoek et al., 2006; Woo et al., 2009). In addition, longitudinal studies of $\mathrm{HCoV}$ epidemiology are lacking (Kuypers et al., 2007; Lau et al., 2006). In the present study, we report a six-year longitudinal epidemiological study of $\mathrm{HCoV}$ infections in patients across all ages in Hong Kong.

\section{MATERIALS AND METHODS}

\section{Patients and microbiological methods}

During the 6-year period (September 2008-August 2014), a total of 8275 nasopharyngeal samples from patients with acute respiratory tract infections admitted to two public hospitals (Queen Mary Hospital and Pamela Youde Nethersole Eastern Hospital) in Hong Kong were included in the present study. All nasopharyngeal samples were negative for influenza A and B viruses, parainfluenza virus types 1,2 and 3, respiratory syncytial virus, adenovirus and metapneumovirus by direct immunofluorescence (van den Hoogen et al., 2001; Woo et al., 1997), and these samples were further tested for human coronaviruses (HCoVs) by reverse transcription polymerase chain reaction (RT-PCR).

RNA extraction

Viral RNA was extracted from the nasopharyngeal samples using EZ1 Virus Mini Kit v2.0 (QIAgen, Hilden, Germany). The RNA was eluted in $60 \mu \mathrm{L}$ of AVE buffer and was used as a template for RT-PCR.

RT-PCR for coronaviruses and DNA sequencing $\mathrm{RT}$ was performed using random hexamers and the $\mathrm{Su}$ perScript III kit (Invitrogen, San Diego, USA) as described previously (Woo et al., 2005a; Woo et al., 2005b). PCR for HCoVs was performed using a primer set (forward primer: 5'-GGTTGGGACTATCCTAAGTGTGA 3' and reverse primer: 5'-CCATCATCAGATAGAATCATCATA -3') targeting a 440-bp RNA dependent RNA polymerase $(R d R p)$ region of $\mathrm{HCoVs}$ (Woo et al., 2005a). The PCR mixture $(25 \mu \mathrm{L})$ contained cDNA, PCR buffer, $200 \mu \mathrm{mol} / \mathrm{L}$ of each dNTPs and 1.0 U Taq polymerase (Boehringer Mannheim, Germany). The mixtures were amplified in 60 cycles of $94{ }^{\circ} \mathrm{C}$ for $1 \mathrm{~min}, 48{ }^{\circ} \mathrm{C}$ for 1 min and $72{ }^{\circ} \mathrm{C}$ for $1 \mathrm{~min}$, and a final extension at $72{ }^{\circ} \mathrm{C}$ for $10 \mathrm{~min}$. The amplified products were detected by agarose gel electrophoresis as described in our previous publication (Woo et al., 2005a). Both strands of all PCR products were sequenced twice with an Applied Biosystems 3130xl DNA Analyzer (Applied Biosystems, Foster City, USA), using the PCR primers. The sequences of the PCR products were compared with the sequences of the RdRp genes of coronaviruses in the GenBank database.

\section{Phylogenetic analysis}

The partial $R d R p$ sequences of $\mathrm{HCoV}$ strains from 77 nasopharyngeal samples were used for phylogenetic tree construction, which was performed using maximum likelihood (ML) method in MEGA5 with the best model GTR $+\mathrm{G}$ (Tamura et al., 2011), with bootstrap values calculated from 1000 trees.

\section{Statistical method}

Statistical analysis was confirmed by IBM SPSS statistics software version 23. Comparisons between patients aged $>80$ years and those of other age groups infected with $\mathrm{HCoV}-\mathrm{OC} 43$ were performed using chi-square test. $P<0.05$ was regarded as statistically significant.

\section{RESULTS}

\section{Respiratory virus detection in nasopharyngeal samples}

During the 6-year period, 8275 nasopharyngeal samples from patients (male:female $=1.03: 1$, age $($ mean \pm SD) $=$ $49 \pm 36$ years) with acute respiratory tract infections were collected from the 2 public hospitals for the present study. HCoVs were detected in $77(0.93 \%)$ nasopharyngeal samples from patients with the median age of 79.5 years (range, 22 days to 95 years). Thirty-seven were males and 40 were females. 
RT-PCR and sequencing of the partial RNAdependent RNA polymerase (RdRp) genes of human coronaviruses and phylogenetic analysis

The partial $R d R p$ genes of $77 \mathrm{HCoV}$ strains detected from the nasopharyngeal samples were amplified and sequenced. The phylogenetic tree was shown in Figure 1.
The nucleotide sequences of the $12 \mathrm{HCoV}$ strains showed $99.5 \%-100 \%$ nucleotide identities to $\mathrm{HCoV}$ $229 \mathrm{E}$, those of the $6 \mathrm{HCoV}$ strains showed $98.9 \%-100 \%$ nucleotide identities to HCoV-NL63, those of the 48 HCoV strains showed $98.6 \%-100 \%$ nucleotide identities to HCoV-OC43 and those of the $11 \mathrm{HCoV}$ strains showed $97 \%-100 \%$ nucleotide identities to $\mathrm{HCoV}$ -

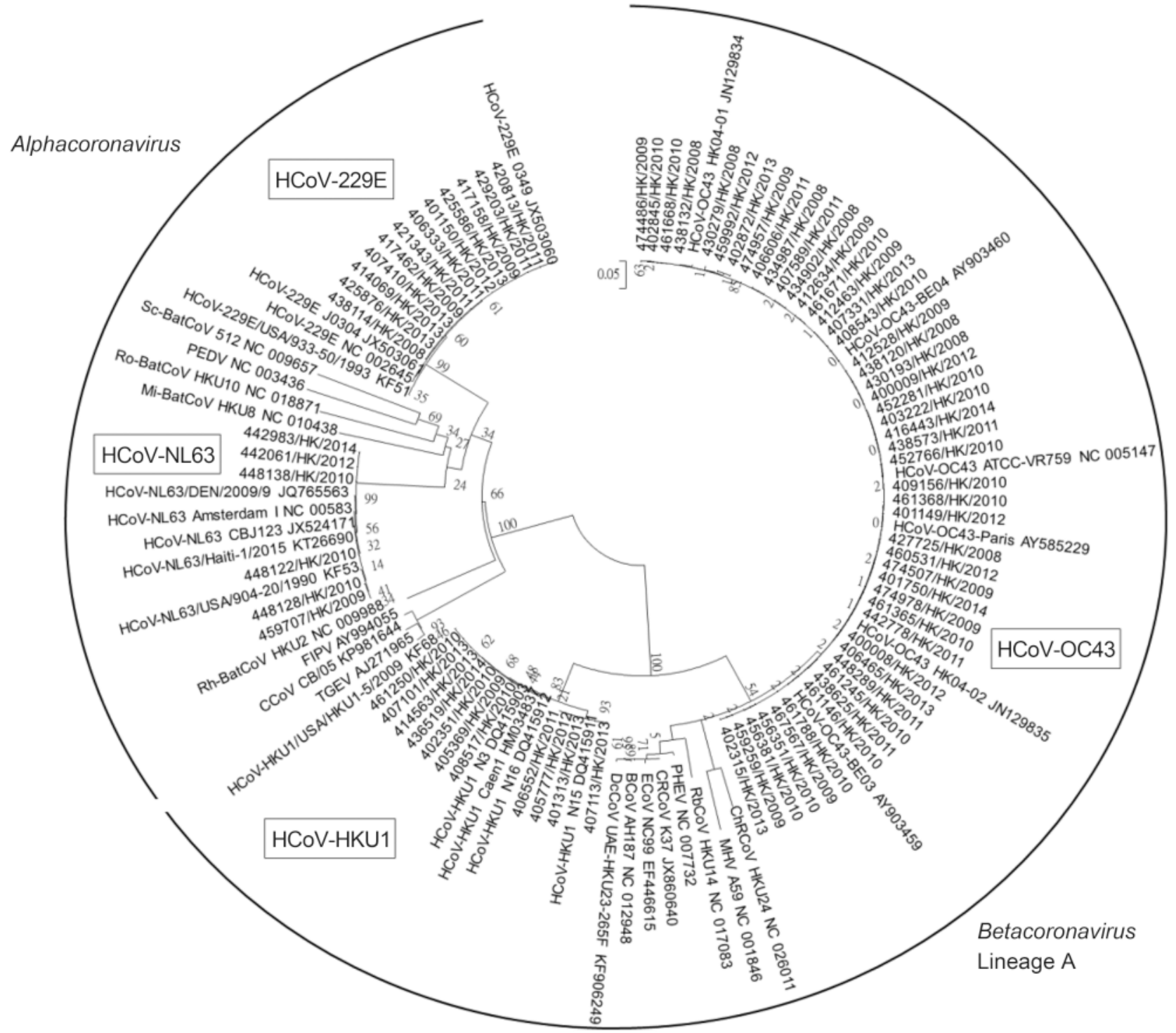

Figure 1. Phylogenetic trees of partial RdRp gene sequences of $77 \mathrm{HCoV}$ strains detected from the nasopharyngeal samples. The tree was inferred from the partial RdRp gene data by ML method, with bootstrap values calculated from 1000 trees. CCoV, canine coronavirus; FIPV, feline infectious peritonitis virus; HCoV-229E, human coronavirus 229E; HCoV-NL63, human coronavirus NL63; Mi-BatCoV HKU8, Miniopterus bat coronavirus HKU8; PEDV, porcine epidemic diarrhea virus; Rh-BatCoV HKU2, Rhinolophus bat coronavirus HKU2; Ro-BatCoV HKU10, Rousettus bat coronavirus HKU10; Sc-BatCoV 512, Scotophilus bat coronavirus 512; TGEV, porcine transmissible gastroenteritis virus; BCoV, bovine coronavirus; ChRCoV HKU24, China Rattus coronavirus HKU24; CRCoV, canine respiratory coronavirus; DcCoV UAE-HKU23, dromedary camel coronavirus UAE-HKU23; ECoV, equine coronavirus; HCoV HKU1, human coronavirus HKU1; HCoV-OC43, human coronavirus OC43; MHV, murine hepatitis virus; PHEV, porcine hemagglutinating encephalomyelitis virus; RCoV, rat coronavirus; RbCoV HKU14, rabbit coronavirus HKU14. 
HKU1. Accordingly, the most frequently detected $\mathrm{HCoV}$ species was HCoV-OC43 (48/8275, 0.58\%), followed by HCoV-229E (12/8275, 0.15\%), HCoV-HKU1 (11/8275, $0.13 \%)$ and HCoV-NL63 (6/8275, 0.07\%) by RT-PCR (Table 1).

\section{Age distribution}

Analysis of age distribution among patients positive for HCoVs showed that HCoVs mainly infected the elderly, with the highest detection frequency $(36 / 2380,1.51 \%)$ in those $>80$ years and the majority of cases infected by HCoV-OC43 (26/36, 72\%) (Table 1). HCoVs also commonly infected children, with the detection rate of $0.91 \%$ $(23 / 2529)$ in the age group of $0-10$ years and about half of the cases infected by HCoV-OC43 (12/23, 52\%). Interestingly, the detection rate of $\mathrm{HCoV}-\mathrm{OC} 43$ in the age group of $>80$ years $(26 / 2380,1.09 \%)$ was significantly higher than the rates in the age groups of $0-10$ years $(12 / 2529,0.47 \%)$ and $71-80$ years $(3 / 1237,0.24 \%)(P<$ 0.05 ) (Table 2). No significant differences were noted between the detection rate of $\mathrm{HCoV}-\mathrm{OC} 43$ in the age group of $>80$ years and the rates in other age groups from 11 to 70 years $(P>0.05)$ (Table 2). None of the samples from patients aged between 11 and 30 years were positive for HCoVs. However, an increasing trend in the detection frequency of HCoVs with age was noted among other age groups, from $0.42 \%(1 / 238)$ in the age group of $31-40$ years to $0.65 \%(4 / 617)$ in the age group of $61-70$ years and $0.57 \%(7 / 1237)$ in patients aged between $71-80$ years.

\section{Seasonal distribution}

HCoVs were detected over the 6-year study period, with the highest and lowest detection rates of $\mathrm{HCoVs}$ noted in

Table 1. Age distribution of nasopharyngeal samples positive for human coronaviruses.

\begin{tabular}{lllllll}
\multirow{2}{*}{$\begin{array}{l}\text { Age group } \\
\text { (years) }\end{array}$} & $\begin{array}{l}\text { Number of } \\
\text { samples }\end{array}$ & HCoVs & HCoV-229E & HCoV-NL63 & HCoV-OC43 & HCoV-HKU1 \\
\hline $0-10$ & 2529 & $23(0.91)$ & $5(0.2)$ & $2(0.08)$ & $12(0.47)$ & $4(0.16)$ \\
$11-20$ & 307 & $0(0)$ & $0(0)$ & $0(0)$ & $0(0)$ & $0(0)$ \\
$21-30$ & 177 & $0(0)$ & $0(0)$ & $0(0)$ & $0(0)$ & $0(0)$ \\
$31-40$ & 238 & $1(0.42)$ & $0(0)$ & $0(0)$ & $1(0.42)$ & $0(0)$ \\
$41-50$ & 323 & $2(0.62)$ & $1(0.31)$ & $0(0)$ & $1(0.31)$ & $0(0)$ \\
$51-60$ & 465 & $3(0.65)$ & $0(0)$ & $1(0.22)$ & $2(0.43)$ & $0(0)$ \\
$61-70$ & 617 & $4(0.65)$ & $1(0.16)$ & $0(0)$ & $2(0.32)$ & $1(0.16)$ \\
$71-80$ & 1237 & $7(0.57)$ & $2(0.16)$ & $1(0.08)$ & $3(0.24)$ & $1(0.08)$ \\
$>80$ & 2380 & $36(1.51)$ & $3(0.13)$ & $2(0.08)$ & $26(1.09)$ & $5(0.21)$ \\
Unknown & 2 & 1 & - & - & 1 & - \\
Total & 8275 & $77(0.93)$ & $12(0.15)$ & $6(0.07)$ & $48(0.58)$ & $11(0.13)$ \\
\hline
\end{tabular}

Table 2. Comparisons between patients aged $>80$ years and those of other age groups infected with $\mathrm{HCoV}-\mathrm{OC} 43$.

\begin{tabular}{llll}
$\begin{array}{l}\text { Age groups } \\
\text { (years) }\end{array}$ & $\begin{array}{l}\text { Number of } \\
\text { samples }\end{array}$ & $\begin{array}{l}\text { No. }(\%) \text { of samples positive } \\
\text { for HCoV-OC43 }\end{array}$ & $P$ value * \\
\hline $0-10$ & 2529 & $12(0.47)$ & 0.014 \\
$11-20$ & 307 & $0(0)$ & 0.066 \\
$21-30$ & 177 & $0(0)$ & 0.162 \\
$31-40$ & 238 & $1(0.42)$ & 0.328 \\
$41-50$ & 323 & $1(0.31)$ & 0.184 \\
$51-60$ & 465 & $2(0.43)$ & 0.186 \\
$61-70$ & 617 & $2(0.32)$ & 0.077 \\
$71-80$ & 1237 & $3(0.24)$ & 0.007 \\
\hline 80 & 2380 & $26(1.09)$ & - \\
\hline
\end{tabular}

Note: ${ }^{*}$ Using $>80$ years old as the reference age group; $P<0.05$ was considered to be statistically significant. 


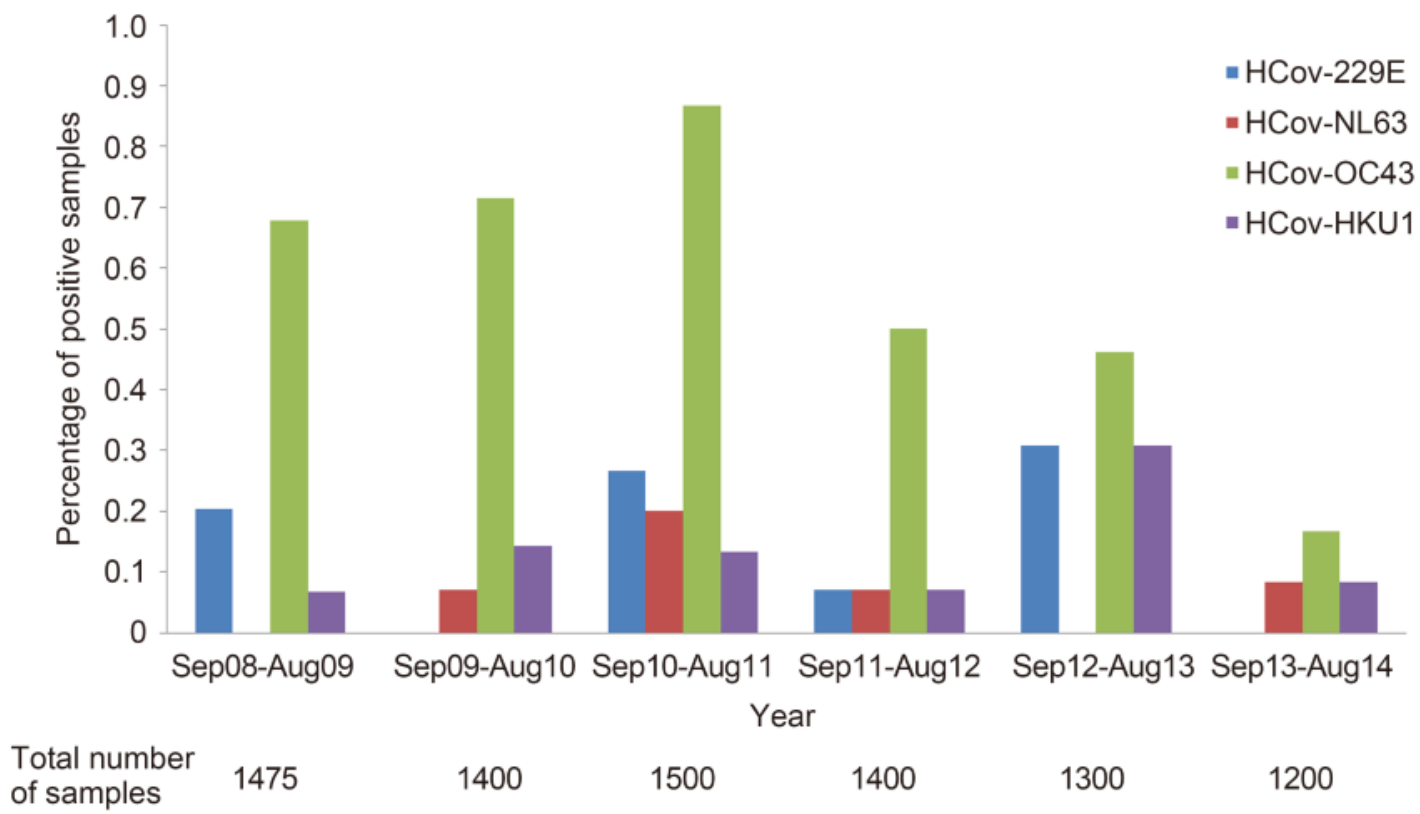

Figure 2. Detection frequency of human coronaviruses identified from the nasopharyngeal samples of patients hospitalized for acute respiratory tract infections during the 6-year period.

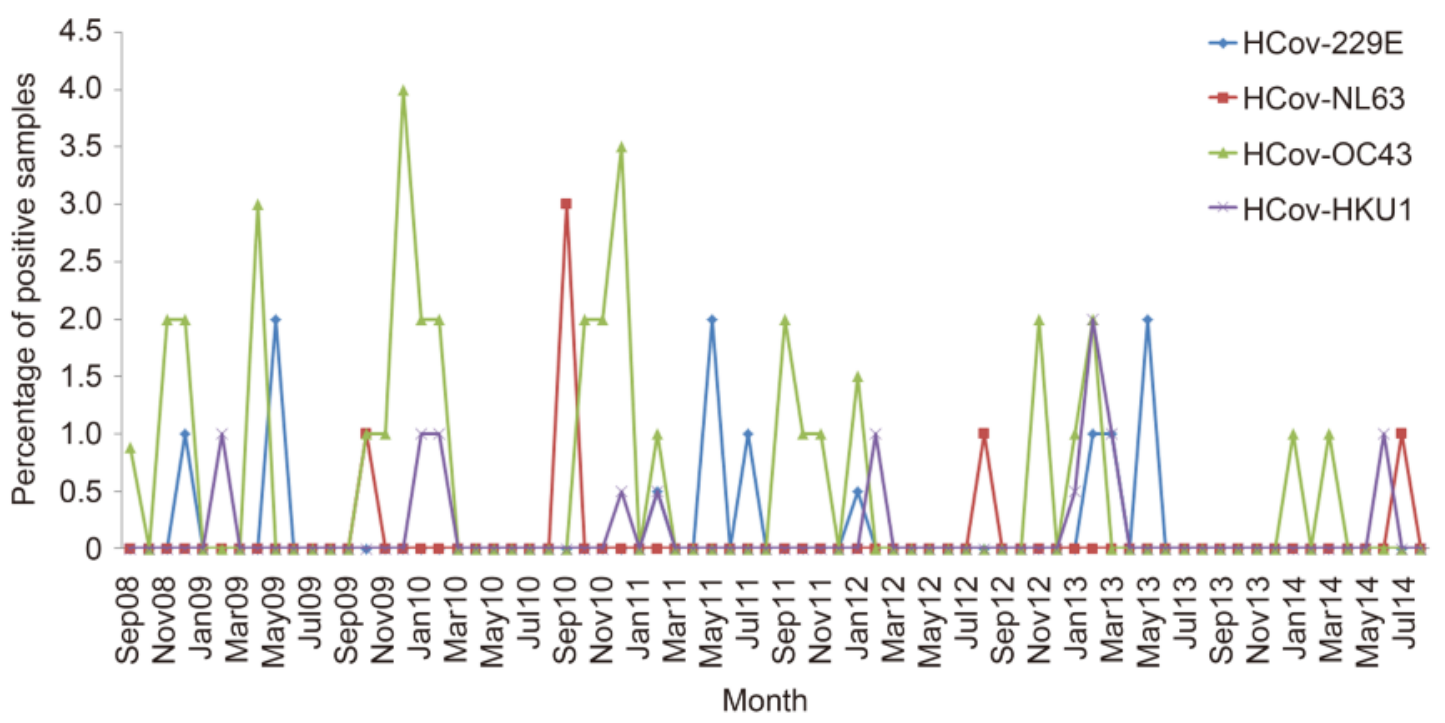

Figure 3. Seasonality of human coronavirus infections in Hong Kong during the study period.

the periods of September 2010-August 2011 (22/1500, $1.47 \%$ ) and September 2013-August 2014 (4/1200, $0.33 \%$ ), respectively (Figure 2). HCoVs were most frequently detected in the fall and winter during the 6-year period, but each $\mathrm{HCoV}$ species displayed different seasonal patterns (Figure 3). HCoV-OC43 was the most frequently detected species throughout all years, with the highest detection rate in the period of September 2010-August 2011 (13/1500, 0.87\%). HCoV-OC43 was predominant in the fall and winter. $\mathrm{HCoV}-\mathrm{HKU} 1$ was also detected throughout all years, with the highest detection rate in the period of September 2012-August
2013 (4/1300, 0.31\%). HCoV-HKU1 infections mainly occurred in winter. HCoV-229E was detected in alternate years [except in September 2011-August 2012, but with very low detection rate $(1 / 1400,0.07 \%)]$, with the highest detection rate in the period of September 2012-August 2013 (4/1300, 0.31\%). HCoV-229E infections mainly occurred in winter and spring, with a few cases occurred in summer in 2011. HCoV-NL63 was the least frequently detected $\mathrm{HCoV}$ species, with the highest detection rate during September 2010-August 2011 $(3 / 1500,0.2 \%)$. HCoV-NL63 was predominant in the summer and fall. 


\section{DISCUSSION}

The present study describes the epidemiology of $\mathrm{HCoV}$ infections in Hong Kong over a 6-period. HCoVs are circulating globally and have been detected in $2.1 \%-18 \%$ of respiratory samples in previous studies (Cabeça et al., 2012; Chung et al., 2007; Dare et al., 2007; Esposito et al., 2006; Gaunt et al., 2010; Lau et al., 2006; Mackay et al., 2012; Njouom et al., 2012; Pierangeli et al., 2007; Prill et al. 2012; Regamey et al., 2008; Sloots et al., 2006; Vabret et al, 2008; Woo et al., 2009). In this study, HCoVs were detected in $0.93 \%$ of the nasopharyngeal samples from patients with acute respiratory illness in all age groups. The incidence of $\mathrm{HCoV}$ infections in this study was apparently lower than those in several other reports (Arden et al., 2005; Bastien et al., 2005; Chiu et al., 2005; Ebihara et al., 2005; Dare et al., 2007; Gaunt et al., 2010; Liu et al., 2014; Moes et al., 2005; Prill et al., 2012), which may be due to different reasons. First, different sampling strategies may have led to different detection rates. $\mathrm{HCoVs}$ are well known to predominate in winter and commonly infect infants and children (Woo et al., 2009). Therefore, studies that include infants or young children only and/or during winter months could result in higher incidence of $\mathrm{HCoV}$ infections. For example, HCoVs were detected in 20 (18\%) of 112 infants with acute respiratory infections in Switzerland (Canducci et al., 2008; Esposito et al., 2006; Mackay et al., 2012; Regamey et al., 2008; Sloots et al., 2006). In this study, only hospitalized patients who may have more severe infections were included, which may have underestimated the overall incidence among all respiratory illnesses. Second, various detection methods may show different sensitivities towards virus detection. Nested PCR and real-time PCR have shown to be more sensitive in detecting $\mathrm{HCoV}-\mathrm{OC} 43$ and 229E when compared to conventional detection assays (Myint et al., 1994; Vijgen et al., 2005). Third, HCoVs may exhibit different geographical variations in incidence. In our previous study, $\mathrm{HCoV}$ was responsible for $2.1 \%$ of admissions for all acute respiratory tract infections during April 2004 to March 2005 (Lau et al., 2006). The apparent lower incidence in the present study may be due to different study periods. Year-to-year variations in the frequency of $\mathrm{HCoV}$ infections have been reported (Lai et al., 2007). In this study, the detection frequency of $\mathrm{HCoVs}$ varied over different years, with the lowest rate of $0.33 \%$ during September 2013 to August 2014, which also reduced the overall detection frequency of HCoVs. Although low prevalence of HCoVs was shown, they can result in severe diseases, such as pneumonia and even death (Patrick et al., 2006; Woo et al., 2005b). The detection of other pathogens in $\mathrm{HCoV}$-positive nasopharyngeal samples is needed to investigate if the co-infections contribute to disease severity in the future. Thus, the impact of HCoVs on public health cannot be neglected. Further study is warranted to examine the seroepidemiology of $\mathrm{HCoV}$ infections in our local population.

$\mathrm{HCoV}-\mathrm{OC} 43$ was the most prevalent among the four $\mathrm{HCoV}$ species during the study period, followed by $\mathrm{HCoV}-229 \mathrm{E}$ and HCoV-HKU1 with similar incidence, and $\mathrm{HCoV}-\mathrm{NL} 63$ of the least importance. Other studies also showed that $\mathrm{HCoV}-\mathrm{OC} 43$ was the most prevailing $\mathrm{HCoV}$ species circulating in China, Thailand, Australia, United Kingdom and the United States (Dare et al., 2007; Gaunt et al., 2010; Lau et al., 2006; Liu et al., 2014; Prill et al., 2012; Sloots et al., 2006), while some studies demonstrated that the prevalence of HCoV-NL63 was similar to or even higher than that of $\mathrm{HCoV}-\mathrm{OC} 43$ in Korea, the Netherlands, Cameroon and Brazil (Cabeça et al., 2013; Chung et al., 2007; Dijkman et al., 2012; Njouom et al., 2012). Dijkman et al. hypothesized that HCoV-OC43 and HCoV-NL63 might elicit immune response that protects against subsequent infections caused by $\mathrm{HCoV}-\mathrm{HKU} 1$ and $\mathrm{HCoV}-229 \mathrm{E}$, respectively, which may explain why HCoV-OC43 and HCoV-NL63 were the most frequently detected $\mathrm{HCoV}$ species (Dijkman et al., 2012). However, HCoV-NL63 was rarely detected in Hong Kong when compared to some other countries (Cabeça et al., 2013; Dijkman et al., 2012), which may be related to geographical variation.

The present study revealed different seasonal patterns of each $\mathrm{HCoV}$ species. It has been reported that $\mathrm{HCoV}$ OC43 and HCoV-HKU1 were predominant in winter months in temperate regions, whereas HCoV-NL63 and HCoV-229E demonstrated different patterns in various geographical regions (Cabeça et al., 2013; Chiu et al., 2005; Gaunt et al., 2010; Lau et al., 2006; Vabret et al., 2003). In the present study conducted in Hong Kong which is a subtropical city, HCoV-OC43 mainly occurred in the fall and winter, whereas HCoV-HKU1 infections peaked in winter, with a few cases occurred in spring and summer, which are consistent with those in other temperate regions (Cabeça et al., 2013; Lau et al., 2006; Mackay et al., 2012). HCoV-NL63 displayed peak activity in winter in the Netherlands (Dijkman et al., 2012; Vabret et al., 2003; van der Hoek et al., 2004), but in Hong Kong, HCoV-NL63 showed summer-autumn predominance, which was in line with our previous findings (Lau et al., 2006). HCoV-229E was usually detected in low levels throughout the year in previous reports (Dare et al., 2007; Lau et al., 2006), and thus, the peak activity of $\mathrm{HCoV}-229 \mathrm{E}$ could not be determined. A few studies showed that HCoV-229E was predominant in winter in Guangzhou and Edinburgh (Gaunt et al., 2010; Liu et al., 2014), while a marked autumn seasonality of HCoV-229E was shown in Brazil (Cabeça et al., 2013). In the present study, $\mathrm{HCoV}-229 \mathrm{E}$ was found to be predominant in winter and spring.

The elderly and young children are usually considered 
more vulnerable to respiratory infections because of their weakened immune system and immature immunity, respectively. In the present study, HCoVs were shown to be most prevalent among the elderly aged $>80$ years, followed by young children $\leq 10$ years (Table 1 ). Interestingly, $\mathrm{HCoV}-\mathrm{OC} 43$ had a significantly higher detection rate in the elderly aged $>80$ years compared to children aged $0-10$ years $(P<0.05)$ (Table 2$)$, which was not observed for other $\mathrm{HCoV}$ species. This finding was in contrast to those in other studies (Dare et al., 2007; Gaunt et al., 2010), in which HCoV-OC43 was more frequently detected in young children than in the elderly. $\mathrm{HCoV}-\mathrm{OC} 43$ is the most prevalent $\mathrm{HCoV}$ species circulating globally and the elderly died of HCoV-OC43 infection in an outbreak was reported (Patrick et al., 2006). Recently, we have also reported the emergence of a recombinant HCoV-OC43 genotype D which was associated with pneumonia in the elderly (Lau et al., 2011). Therefore, continuous surveillance would be required to ascertain if $\mathrm{HCoV}-\mathrm{OC} 43$ poses a significant public health impact on the elderly, particularly those aged $>80$ years and institutionalized in elderly homes in Hong Kong. Moreover, further studies should be performed to understand the evolution of these $\mathrm{HCoVs}$ and potential for re-emergence.

\section{ACKNOWLEDGMENTS}

We thank Dr. Wing-Man Ko, Secretary for Food and Health Bureau and Dr Constance Hon-Yee Chan, Director of Health for facilitation and support. Views expressed in this paper are those of the authors only, and may not represent the opinion of the Government of the HKSAR. This work is partly supported by the ThemeBased Research Scheme, University Grant Council; Strategic Research Theme Fund and University Development Fund, The University of Hong Kong; Health and Medical Research Fund of the Food and Health Bureau of HKSAR; and Consultancy Service for Enhancing Laboratory Surveillance of Emerging Infectious Disease for the HKSAR Department of Health.

\section{COMPLIANCE WITH ETHICS GUIDELINES}

Additional informed consent was obtained from all patients for which identifying information is included in this article.

\section{AUTHOR CONTRIBUTIONS}

CCYY, KYY, PCYW and SKPL designed the study. CCYY, CSFL, HKHL, EYMW and SKPL performed research and analyzed data. RAL, LYS, KHC, VCCC, KYY, PCYW and SKPL provided materials and data.
CCYY and SKPL wrote the manuscript. All authors read and approved the final manuscript.

\section{REFERENCES}

Arden KE, Nissen MD, Sloots TP, MacKay IM. 2005. New human coronavirus, HCoV-NL63, associated with severe lower respiratory tract disease in Australia. J Med Virol, 75:455-462.

Assiri A, McGeer A, Perl TM, Price CS, Al Rabeeah AA, Cummings DA, Alabdullatif ZN, Assad M, Almulhim A, Makhdoom H, Madani H, Alhakeem R, Al-Tawfiq JA, Cotten M, Watson SJ, Kellam P, Zumla AI, Memish ZA. KSA MERSCoV Investigation Team. 2013. Hospital outbreak of Middle East respiratory syndrome coronavirus. N Engl J Med, 369:407416.

Bastien N, Anderson K, Hart L, Van Caeseele P, Brandt K, Milley D, Hatchette T, Weiss EC, Li Y. 2005. Human coronavirus NL63 infection in Canada. Clin Infect Dis, 191:503-506.

Cabeça TK, Granato C, Bellei N. 2013. Epidemiological and clinical features of human coronavirus infections among different subsets of patients. Influenza Other Respir Viruses, 7:1040-1047.

Canducci F, Debiaggi M, Sampaolo M, Marinozzi MC, Berre S, Terulla C, Gargantini G, Cambieri P, Romero E, Clementi M. 2008. Two-year prospective study of single infections and coinfections by respiratory syncytial virus and viruses identified recently in infants with acute respiratory disease. J Med Virol, 80:716-723.

Chiu SS, Chan KH, Chu KW, Kwan SW, Guan Y, Poon LL, Peiris JS. 2005. Human coronavirus NL63 infection and other coronavirus infections in children hospitalized with acute respiratory disease in Hong Kong, China. Clin Infect Dis, 40:17211729.

Chung JY, Han TH, Kim SW, Kim CK, Hwang ES. 2007. Detection of viruses identified recently in children with acute wheezing. J Med Virol, 79:1238-1243.

Dare RK, Fry AM, Chittaganpitch M, Sawanpanyalert P, Olsen SJ, Erdman DD. 2007. Human coronavirus infections in rural Thailand: a comprehensive study using real-time reverse-transcription polymerase chain reaction assays. J Infect Dis, 196:13211328.

Dijkman R, Jebbink MF, Gaunt E, Rossen JW, Templeton KE, Kuijpers TW, van der Hoek L. 2012. The dominance of human coronavirus OC43 and NL63 infections in infants. J Clin Virol, 53:135-139.

Ebihara T, Endo R, Ma X, Ishiguro N, Kikuta H. 2005. Detection of human coronavirus NL63 in young children with bronchiolitis. J Med Virol, 75:463-465.

Esposito S, Bosis S, Niesters HG, Tremolati E, Begliatti E, Rognoni A, Tagliabue C, Principi N, Osterhaus AD. 2006. Impact of human coronavirus infections in otherwise healthy children who attended an emergency department. J Med Virol, 78:1609-1615.

Fouchier RA, Hartwig NG, Bestebroer TM, Niemeyer B, de Jong JC, Simon JH, Osterhaus AD. 2004. A previously undescribed coronavirus associated with respiratory disease in humans. Proc Natl Acad Sci USA, 101:6212-6216.

Gaunt ER, Hardie A, Claas EC, Simmonds P, Templeton KE. 2010. Epidemiology and clinical presentations of the four human coronaviruses 229E, HKU1, NL63, and OC43 detected over 3 years using a novel multiplex real-time PCR method. J Clin Microbiol, 48:2940-2947.

Hu Q, Lu R, Peng K, Duan X, Wang Y, Zhao Y, Wang W, Lou Y, Tan W. 2014. Prevalence and genetic diversity analysis of human coronavirus OC43 among adult patients with acute respiratory infections in Beijing, 2012. PLoS One, 9:e100781. 
Kaplan NM, Dove W, Abd-Eldayem SA, Abu-Zeid AF, Shamoon HE, Hart C. 2008. Molecular epidemiology and disease severity of respiratory syncytial virus in relation to other potential pathogens in children hospitalized with acute respiratory infection in Jordan. J Med Virol, 80:168-174.

Koetz A, Nilsson P, Lindén M, van der Hoek L, Ripa T. 2006. Detection of human coronavirus NL63, human metapneumovirus and respiratory syncytial virus in children with respiratory tract infections in south-west Sweden. Clin Microbiol Infect, 12:1089-1096.

Kuypers J, Martin ET, Heugel J, Wright N, Morrow R, Englund JA. 2007. Clinical disease in children associated with newly described coronavirus subtypes. Pediatrics, 119:e70-e76.

Lai MMC, Perlman S, Anderson LJ. 2007. Coronaviridae. In: Fields Virology, 5th ed. Knipe DM, Howley PM, Griffin DE, et al (Eds). Philadelphia: Lippincott Williams \& Wilkins, pp. 1305.

Lau SK, Lee P, Tsang AK, Yip CC, Tse H, Lee RA, So LY, Lau YL, Chan KH, Woo PC, Yuen KY. 2011. Molecular epidemiology of human coronavirus OC43 reveals evolution of different genotypes over time and recent emergence of a novel genotype due to natural recombination. J Virol, 85:11325-11337.

Lau SK, Woo PC, Yip CC, Tse H, Tsoi HW, Cheng VC, Lee P, Tang BS, Cheung CH, Lee RA, So LY, Lau YL, Chan KH, Yuen KY. 2006. Coronavirus HKU1 and other coronavirus infections in Hong Kong. J Clin Microbiol, 44:2063-2071.

Liu WK, Liu Q, Chen de H, Liang HX, Chen XK, Chen MX, Qiu SY, Yang ZY, Zhou R. 2014. Epidemiology of acute respiratory infections in children in Guangzhou: a three-year study. PLoS One, 9:e96674.

Mackay IM, Arden KE, Speicher DJ, O'Neil NT, McErlean PK, Greer RM, Nissen MD, Sloots TP. 2012. Co-circulation of four human coronaviruses ( $\mathrm{HCoVs})$ in Queensland children with acute respiratory tract illnesses in 2004. Viruses, 4:637-653.

McIntosh K, Kapikian AZ, Turner HC, Hartley JW, Parrott RH, Chanock RM. 1970. Seroepidemiologic studies of coronavirus infection in adults and children. Am J Epidemiol, 91:585-592.

Moes E, Vijgen L, Keyaerts E, Zlateva K, Li S, Maes P, Pyrc K, Berkhout B, van der Hoek L, Van Ranst M. 2005. A novel pancoronavirus RT-PCR assay: frequent detection of human coronavirus NL63 in children hospitalized with respiratory tract infections in Belgium. BMC Infect Dis, 5:6.

Myint S, Johnston S, Sanderson G, Simpson H. 1994. Evaluation of nested polymerase chain methods for the detection of human coronaviruses 229E and OC43. Mol Cell Probes, 8:357-364.

Njouom R, Yekwa EL, Cappy P, Vabret A, Boisier P, Rousset D. 2012. Viral etiology of influenza-like illnesses in Cameroon, January-December 2009. J Infect Dis, 206:S29-S35.

Oh MD, Choe PG, Oh HS, Park WB, Lee SM, Park J, Lee SK, Song JS, Kim NJ. 2015. Middle East Respiratory Syndrome Coronavirus Superspreading Event Involving 81 Persons, Korea 2015. J Korean Med Sci, 30:1701-1705.

Patrick DM, Petric M, Skowronski DM, Guasparini R, Booth TF, Krajden M, McGeer P, Bastien N, Gustafson L, Dubord J, Macdonald D, David ST, Srour LF, Parker R, Andonov A, IsaacRenton J, Loewen N, McNabb G, McNabb A, Goh SH, Henwick S, Astell C, Guo JP, Drebot M, Tellier R, Plummer F, Brunham RC. 2006. An Outbreak of Human Coronavirus OC43 Infection and Serological Cross-reactivity with SARS Coronavirus. Can J Infect Dis Med Microbiol, 17:330-336.

Peiris JS, Lai S T, Poon L L, Guan Y, Yam LY, Lim W, Nicholls J, Yee WK, Yan WW, Cheung MT, Cheng VC, Chan KH, Tsang DN, Yung RW, Ng TK, Yuen KY, SARS study group. 2003. Coronavirus as a possible cause of severe acute respiratory syndrome. Lancet, 361:1319-1325.

Pierangeli A, Gentile M, Di Marco P, Pagnotti P, Scagnolari C,
Trombetti S, Lo Russo L, Tromba V, Moretti C, Midulla F, Antonelli G. 2007. Detection and typing by molecular techniques of respiratory viruses in children hospitalized for acute respiratory infection in Rome, Italy. J Med Virol, 79:463-468.

Prill MM, Iwane MK, Edwards KM, Williams JV, Weinberg GA, Staat MA, Willby MJ, Talbot HK, Hall CB, Szilagyi PG, Griffin MR, Curns AT, Erdman DD; New Vaccine Surveillance Network. 2012. Human coronavirus in young children hospitalized for acute respiratory illness and asymptomatic controls. Pediatr Infect Dis J, 31:235-240.

Regamey N, Kaiser L, Roiha HL, Deffernez C, Kuehni CE, Latzin P, Aebi C, Frey U. 2008. Viral etiology of acute respiratory infections with cough in infancy: a community-based birth cohort study. Pediatr Infect Dis J, 27:100-105.

Sloots TP, McErlean P, Speicher DJ, Arden KE, Nissen MD, Mackay IM. 2006. Evidence of human coronavirus HKU1 and human bocavirus in Australian children. J Clin Virol, 35:99-102.

Tamura K, Peterson D, Peterson N, Stecher G, Nei M, Kumar S. 2011. MEGA5: molecular evolutionary genetics analysis using maximum likelihood, evolutionary distance, and maximum parsimony methods. Mol Biol Evol, 28:2731-2739.

Theamboonlers A, Samransamruajkit R, Thongme C, Amonsin A, Chongsrisawat V, Poovorawan Y. 2007. Human coronavirus infection among children with acute lower respiratory tract infection in Thailand. Intervirology, 50:71-77.

Vabret A, Dina J, Gouarin S, Petitjean J, Tripey V, Brouard J, Freymuth F. 2008. Human (nonsevere acute respiratory syndrome) coronavirus infections in hospitalised children in France. J Paediatr Child Health, 44:176-181.

Vabret A, Mourez T, Gouarin S, Petitjean J, Freymuth F. 2003. An outbreak of coronavirus OC43 respiratory infection in Normandy, France. Clin Infect Dis, 36:985-989.

van den Hoogen BG, de Jong JC, Groen J, Kuiken T, de Groot R, Fouchier RA, Osterhaus AD. 2001. A newly discovered human pneumovirus isolated from young children with respiratory tract disease. Nat Med, 7:719-724.

van der Hoek L, Pyrc K, Berkhout B. 2006. Human coronavirus NL63, a new respiratory virus. FEMS Microbiol Rev, 30:760773.

van der Hoek L, Pyrc K, Jebbink MF, Vermeulen-Oost W, Berkhout RJ, Wolthers KC, Wertheim-van Dillen PM, Kaandorp J, Spaargaren J, Berkhout B. 2004. Identification of a new human coronavirus. Nat Med, 10:368-373.

Vijgen L, Keyaerts E, Moës E, Maes P, Duson G, Van Ranst M. 2005. Development of one-step, real-time, quantitative reverse transcriptase PCR assays for absolute quantitation of human coronaviruses OC43 and 229E. J Clin Microbiol, 43:5452-5456.

Woo PC, Chiu SS, Seto WH, Peiris M. 1997. Cost-effectiveness of rapid diagnosis of viral respiratory tract infections in pediatric patients. J Clin Microbiol, 35:1579-1581.

Woo PC, Lau SK, Chu CM, Chan KH, Tsoi HW, Huang Y, Wong BH, Poon RW, Cai JJ, Luk WK, Poon LL, Wong SS, Guan Y, Peiris JS, Yuen KY. 2005a. Characterization and complete genome sequence of a novel coronavirus, coronavirus HKU1, from patients with pneumonia. J Virol, 79:884-895.

Woo PC, Lau SK, Tsoi HW, Poon RW, Chu CM, Lee RA, Luk WK, Wong GK, Wong BH, Cheng VC, Tang BS, Wu A, Yung RW, Chen HL, Guan Y, Chan KH, Yuen KY. 2005b. Clinical and molecular epidemiological features of coronavirus HKU1associated community-acquired pneumonia. J Infect Dis, 191:1898-1907.

Woo PC, Lau SK, Yip CC, Huang Y, Yuen KY. 2009. More and More Coronaviruses: Human Coronavirus HKU1. Viruses, 1:57-71.

Zumla A, Hui DS, Perlman S. 2015. Middle East respiratory syndrome. Lancet, 386:995-1007. 